\title{
Serum hepatitis after open-heart surgery
}

\author{
EUNICE LOCKEY ${ }^{1}$, YVONNE COSSART, and \\ LORENZO GONZALEZ-LA VIN
}

\author{
National Heart Hospital and Virus Reference Laboratory, Colindale, London
}

Ten cases of serum hepatitis occurring after open-heart surgery at the National Heart Hospital, London are reported. The incidence seemed to be rising and was at least $2 \%$ before antigenscreened blood became available. Investigation of 135 patients for the presence of Australia antigen and antibody showed that five $(3.7 \%)$ had responses to exposure to the infective agent. All were and remained clinically well, but such patients may constitute a source of infection. Since tested blood has been used no hepatitis cases have been recognized.

Serum hepatitis seems to be a rare complication of open-heart surgery in this country, despite the use of large volumes of blood. We report our experience at the National Heart Hospital, London, and the result of a survey of patients for the presence of Australia antigen before and after open-heart surgery.

\section{PATIENTS AND METHODS}

Hospital records and reports from family doctors have been used to find cases of serum hepatitis occurring within six months of surgery in the 1,516 patients successfully operated upon between January 1964 and June 1971. Follow-up arrangements for these patients include routine outpatient visits after three months and six months, so it is unlikely that many clinical cases of hepatitis have escaped attention.

Between May 1970 and April 1971, all adult patients had preoperative blood samples taken for Australia antigen testing and as many as possible were followed for up to six months after surgery. No attempt was made to obtain blood samples via general practitioners nor to bring patients back to hospital at particular intervals especially for the survey.

Adequate numbers of samples were obtained in this way from 135 of a possible 265 patients. The samples were tested for the presence of Australia antigen and antibody by the gel diffusion test of Prince (1968) and by countercurrent electrophoresis (Pesendorfer, Krassnitsky, and Wewalka, 1970).

The blood, plasma, and fibrinogen used in the unit were obtained from the National Blood Transfusion Service and at this time were not screened for the

1Plcase address all correspondence to: Dr. E. Lockey, Nationa Heart Hospital, Westmoreland Street, London W1M 8BA presence of Australia antigen. When fresh blood was required, it was obtained from a small volunteer panel maintained by the hospital.

\section{RESULTS}

EXPERIENCE OF SERUM HEPATITIS Table I gives the incidence of clinical hepatitis. No cases were reported in the 435 patients operated upon in the four-year period 1964-67. There was one case out of 274 in 1968 and one out of 306 in 1969. In 1970, four patients out of 302 contracted the

T A B LE I

INCIDENCE OF CLINICAL HEPATITIS

\begin{tabular}{l|c|c|c}
\hline Period & $\begin{array}{c}\text { Patients with } \\
\text { Hepatitis }\end{array}$ & $\begin{array}{c}\text { No. of } \\
\text { Operations }\end{array}$ & Incidence \\
\hline $1964-67$ & None & 435 & Nil \\
1968 & 1 & 274 & $0 \cdot 4 \%$ \\
1969 & 1 & 306 & $0 \cdot 3 \%$ \\
1970 & 4 & 302 & $1 \cdot 3 \%$ \\
Jan.-June & 4 & 199 & $2 \cdot 0 \%$ \\
1971 & & & \\
\hline
\end{tabular}

T A B L E I I

PERIOD BETWEEN OPERATION AND ONSET OF CLINICAL HEPATITIS

\begin{tabular}{|c|c|c|c|c|}
\hline Patient & Year & $\begin{array}{c}\text { Incubation } \\
\text { Period } \\
\text { (weeks) }\end{array}$ & $\begin{array}{l}\text { Test for } \\
\text { Australia } \\
\text { Antigen }\end{array}$ & Outcome \\
\hline 1 & 1968 & $\begin{array}{l}18 \text { after } \\
\text { perfusion } 8 \text { after } \\
\text { haematemesis }\end{array}$ & Not done & Died \\
\hline $\begin{array}{r}2 \\
3 \\
4 \\
5 \\
6 \\
7 \\
8 \\
9 \\
10\end{array}$ & $\begin{array}{l}1969 \\
1970 \\
1970 \\
1970 \\
1970 \\
1971 \\
1971 \\
1971 \\
1971\end{array}$ & $\begin{array}{r}13 \\
15 \\
9 \\
17 \\
13 \\
7 \\
15 \\
10 \\
14\end{array}$ & $\begin{array}{l}\text { Not done } \\
\text { Positive } \\
\text { Not done } \\
\text { Positive } \\
\text { Positive } \\
\text { Negative } \\
\text { Positive } \\
\text { Negative } \\
\text { Positive }\end{array}$ & $\begin{array}{l}\text { Lived } \\
\text { Died } \\
\text { Died } \\
\text { Lived } \\
\text { Lived } \\
\text { Lived } \\
\text { Lived } \\
\text { Lived } \\
\text { Lived }\end{array}$ \\
\hline
\end{tabular}


disease together with one surgeon, while another four cases of hepatitis occurred in the 199 patients operated upon in the first six months of 1971. The known incidence has risen from nil to $2 \%$.

All 10 cases occurred between seven and 18 weeks after surgery. Five were positive for Australia antigen with onset between 13 and 17 weeks after surgery (average 15 weeks); two were negative with onset between seven and 10 weeks after surgery; three were not tested (Table II). The surgeon was Australia antigen negative. He had not been in contact with a known case of hepatitis but had been concerned in the care of two of the patients who developed it later. One of these was known to be Australia antigen positive.

Three patients died of the disease. All were sick before surgery and had complicated postoperative courses. One patient needed an 8-unit blood transfusion 10 weeks after surgery because of haematemesis. She became jaundiced eight weeks after this and died within a few days. It is conjectural, therefore, if transfusion at the time of surgery was responsible for her hepatitis. All three patients died within a few days of becoming jaundiced. Histology revealed widespread destruction of the hepatic architecture. Hepatocellular necrosis was virtually complete in one of them, the only undamaged cells being those of the biliary ductules and vascular tree. In the other two patients, diffuse interstitial lymphocyte aggregates were present with lymphocyte infiltration of the portal tracts. Surviving parenchymal cells showed fatty change, and Kuppfer cells appeared prominent.

RESULTS OF AUSTRALIA ANTIGEN SURVEY In the Australia antigen survey, 135 patients were tested. Three became antigen positive and two developed antibody. Tests became positive between three and seven weeks after surgery and remained so for up to 24 weeks.

One patient showed a very weak positive test on the day following surgery, presumably indicating a direct transfer of antigen from some of the transfused blood. Thus five patients $(3.7 \%)$ of those tested showed evidence of exposure to the infective agent but none developed clinical evidence of the disease within six months of surgery.

During the 11-month period of the survey, four $(3.1 \%)$ of the 130 patients not included in it developed clinical hepatitis and three proved to be Australia antigen positive. These four patients received relatively small volumes of blood $(6,7$, 8 , and 12 units respectively), the average for each operation in the survey period being 10 units. The five patients who were known to have serological evidence of exposure to the infective agent but who never developed the clinical disease received more $(9,14,21,29$, and 37 units respectively). Five of these nine patients also received fibrinogen and four had fresh frozen plasma (Table III).

\section{T A B LE II I}

BLOOD AND BLOOD PRODUCTS USED BY PATIENTS WITH CLINICAL HEPATITIS OR SEROLOGICAL EVIDENCE OF EXPOSURE TO THE VIRUS

\begin{tabular}{|c|c|c|c|c|c|}
\hline Patient & $\begin{array}{l}\text { Total } \\
\text { Blood } \\
\text { (pints) }\end{array}$ & $\begin{array}{l}\text { Fresh } \\
\text { Blood }\end{array}$ & $\begin{array}{c}\text { Fresh Frozen } \\
\text { Plasma }\end{array}$ & $\begin{array}{c}\text { Fibrino- } \\
\text { gen }\end{array}$ & Diagnosis \\
\hline $\begin{array}{r}2 \\
3 \\
4 \\
9 \\
10\end{array}$ & $\begin{array}{r}48 \\
8 \\
16 \\
18 \\
18 \\
15 \\
10 \\
14\end{array}$ & $\begin{array}{l}\text { Yes } \\
\text { Not } \\
\text { known } \\
\text { Yes } \\
\text { Yes } \\
\text { Yes } \\
\text { No } \\
\text { Yes }\end{array}$ & $\begin{array}{l}\text { No } \\
\text { Not } \\
\text { known } \\
\text { No } \\
\text { Yes } \\
\text { Yes } \\
\text { No } \\
\text { Yes }\end{array}$ & $\begin{array}{l}\text { No } \\
\text { Not } \\
\text { known } \\
\text { No } \\
\text { No } \\
\text { Yes } \\
\text { Yes } \\
\text { Yes }\end{array}$ & $\begin{array}{l}\text { Clinical } \\
\text { Clinical } \\
\text { Clinical } \\
\text { Clinical } \\
\text { Clinical } \\
\text { Clinical }\end{array}$ \\
\hline $\begin{array}{r}\text { urvey } \\
5 \\
6 \\
7 \\
8 \\
11 \\
12 \\
13 \\
14 \\
15\end{array}$ & $\begin{array}{r}\text { iod } \\
7 \\
8 \\
6 \\
12 \\
29 \\
9 \\
21 \\
37 \\
14\end{array}$ & $\begin{array}{l}\text { No } \\
\text { No } \\
\text { No } \\
\text { No } \\
\text { Yes } \\
\text { No } \\
\text { Yes } \\
\text { Yes } \\
\text { No }\end{array}$ & $\begin{array}{l}\text { No } \\
\text { No } \\
\text { Yes } \\
\text { No } \\
\text { Yes } \\
\text { No } \\
\text { Yes } \\
\text { Yes } \\
\text { No }\end{array}$ & $\begin{array}{l}\text { No } \\
\text { Yes } \\
\text { No } \\
\text { Yes } \\
\text { Yes } \\
\text { No } \\
\text { Yes } \\
\text { Yes } \\
\text { No }\end{array}$ & $\begin{array}{l}\text { Clinical } \\
\text { Clinical } \\
\text { Clinical } \\
\text { Clinical } \\
\text { Serological } \\
\text { Serological } \\
\text { Serological } \\
\text { Serological } \\
\text { Serological }\end{array}$ \\
\hline
\end{tabular}

\section{DISCUSSION}

Clinical hepatitis follows less than $1 \%$ of blood transfusions in this country (M.R.C., 1954; Lendrum, 1972), but patients undergoing openheart surgery are at special risk because numerous donors are involved in providing the relatively large amounts of blood and blood products used for each operation. In some centres in the United States almost half the patients have developed hepatitis (icteric and non-icteric) after open-heart surgery. This high incidence is attributable to the use of blood from paid donors, many of whom are prisoners, alcoholics or drug addicts and unwilling to admit to previous hepatitis since this would deprive them of a source of income (Allen, 1970). When blood from volunteers is used, hepatitis is rare in the recipients (Walsh et al., 1970).

In our hospital, hepatitis after open-heart operations has been increasing to an unacceptable level, although all the blood used has been from volunteer donors. It is hard to assess whether this increase reflects an increasing incidence of hepatitis in Britain because the disease has been notifiable only since 1968 . However, the trend in the United States has been for an increase in cases among young adults. These are largely of the 
serum hepatitis type and related to the widespread abuse of drugs in this age group (Gregg, 1972). It is not known if the hepatitis carrier rate in volunteer donors in the United States has also been rising.

The discovery of Australia antigen by Blumberg, Alter, and Visnich in 1965 has provided a laboratory marker for the 'viraemic' phase of 'serum hepatitis'. It appears in the serum between two weeks and six months after inoculation or transfusion of infectious material, and a very high concentration is reached about the time of onset of symptoms. Thereafter it declines at a variable rate but antigen tests become negative in most patients 6 to 12 weeks after the onset of hepatitis. The antigen consists of virus-like particles whose morphology is sufficiently characteristic to be identifiable by electron microscopy. Australia antigen is specifically related to the long-incubation type of hepatitis, but no corresponding specific antigen is produced in the short-incubation or 'infectious' type.

More than two-thirds of the cases tested from the National Heart Hospital were of the antigen positive type, and the serological survey showed that almost $4 \%$ of patients were exposed to Australia antigen around the time of operation.

This may have been via the whole blood transfused, via fresh frozen plasma or fibrinogen (Boeve, Winterscheid, and Merendino, 1969), or may have arisen as a result of hospitalization itself. During the period of the survey most of the blood used came from a single blood transfusion centre, where the Australia antigen carrier rate was subsequently found to be about $0.1 \%$ (Cleghorn, 1972). Fresh frozen plasma and fibrinogen were at that time derived from pools of blood donations which had not been screened for the presence of Australia antigen.

It is of interest that no cases of hepatitis are known in the 12 months which have elapsed since the survey ended. This coincides with the intro- duction of routine Australia antigen screening of both whole blood and blood products. The rejection for transfusion of blood containing $\frac{\bar{\sigma}}{\bar{\omega}}$ Australia antigen seems to have reduced substan- $\vec{\sigma}$

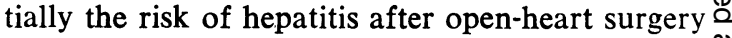
in this hospital. For the present, however, it may be wise to test patients needing re-operation or $\overrightarrow{0}$ cardiac catheterization within six months of $\rightarrow$ operation so that special precautions against cross- $\vec{\omega}$ infection can be instituted for Australia antigen $\stackrel{2}{P}$ positive patients who cannot be deferred. Rapid $\vec{x}$ screening tests are now available which should $N_{\infty}^{N}$ prove satisfactory for screening fresh blood. i

There are as yet no laboratory tests for the $\vec{\infty}$ specific diagnosis of 'infectious hepatitis' which ${ }^{\infty}$ caused about one-third of the cases reported here, $\frac{\text { ㅇ }}{-}$ and this type of infection will assume more im- portance as control of 'serum hepatitis' becomes more effective.

\section{REFERENCES}

Allen, J. G. (1970). Our commercial blood program and serum hepatitis. (Editorial). Ann. Surg., 172, 927.

Blumberg, B. S., Alter, H. J., and Visnich, S. (1965). A "new" antigen in leukemia sera. J. Amer. med. Ass., 191, 541.

Boeve, N. R., Winterscheid, L. C., and Merendino, K. A. ̊ำ (1969). Fibrinogen-transmitted hepatitis in the surgical $\frac{}{D}$ patient. Ann. Surg., 170, 833.

Cleghorn, T. (1972). Personal communication.

Gregg, M. A. (1972). The changing epidemiology of viral hepatitis in the United States. Amer. J. Dis. Child., כ (In press).

Medical Research Council Report (1954). Homologous serum jaundice. Lancet, 1, 1328.

Lendrum, R. (1972). Personal communication. Medical 응 Research Council Report. (In press).

Pesendorfer, F., Krassnitsky, O., and Wewalka, F. (1970). Immunoelektrophoretischer Nachweis von 'Hepatitis-3. Associated Antigen'. Klin. Wschr., 48, 58.

Prince, A. M. (1968). An antigen detected in the blood during the incubation period of serum hepatitis. Proc. nat. Acad. Sci. (Wash.), 60, 814.

Walsh, J. H., Purcell, R. H., Morrow, A. G., Chanock, R. M., D and Schmidt, P. J. (1970). Post-transfusion hepatitis after open-heart operations. J. Amer. med. Ass., 211, 261. N 